\title{
A poética da morte: Formas Animadas..., imaginação, projeção(ões) e infâncias em cena
}

The poetics of death:

Animated Forms..., imagination, projection(s) and on-scene childhoods

Lucas Larcher ${ }^{1}$

1.

Professor substituto do curso de graduação em Teatro da Universidade Federal de Uberlândia. Mestre em Artes

\section{RESUMO}

Este artigo versa sobre possíveis aproximações entre o Teatro de Formas Animadas e o Teatro Infantojuvenil, através da experiência na criação e nas apresentações do espetáculo O Mensageiro do Rei, em Uberlândia - MG, no ano de 2014. Extraindo exemplos da montagem supracitada, elaboro reflexões e discussões acerca de questões que puderam ser (des)/(re) veladas pela presença da animação na peça, e que podem ser redimensionadas para outros espetáculos e/ou contextos.

Palavras-chave: Formas animadas. Teatro infantojuvenil. Infância(s).

(Teatro) pelo Programa de Pós-Graduação em Artes da Universidade Federal de Uberlândia (PPGAR-UFU), e graduado em Teatro pela mesma instituição, com bolsa de Graduação Sanduíche no Exterior (CNPq-CAPES) na Universidade de Évora, em Portugal.

Contato:

lclarcher@hotmail.com ORCID: http://orcid.org/ 0000-0002-8988-0192

Submetido em: 06/12/2016, aceito em: 19/12/2016.

\section{ABSTRACT}

This article deals with possible approximations between the Theater of Animated Forms and the Theater for Children and Youth through the shared experience of the creative process and the presentations of the play called The King's Messenger, produced in Uberlândia - MG, in 2014. Withdrawing examples of the mentioned play, I elaborate reflections and discussions about issues that could be (dis)/(re) veiled by the presence of the animation in the piece, and that can be reconsidered for other plays and/ or contexts as well.

Keywords: Animated forms. Children's theater. Childhood(s). 


\section{Me vejo no que vejo Como entrar por meus olhos \\ Em um olho mais límpido \\ Me olha o que eu olho \\ É minha criação Isto que vejo \\ Octavio Paz}

2.

Este texto é uma adaptação resumida do capítulo terceiro da dissertação de mestrado do autor, intitulada Inventariando O Mensageiro do Rei - reflexões e discussões acerca do Teatro Infantojuvenil (2016).

algumas crianças e também um falso faquir. Nos pensamentos do pequeno enfermo, montanhas, rios, oceanos, ilhas, aldeias distantes e histórias fantásticas ganham forma através da imaginação de quem não pode sair de casa. Estas são algumas das imagens que me vêm à mente ao falar de $O$ Mensageiro do Rei.

Escrita pelo primeiro não europeu a conquistar o prêmio Nobel de Literatura, o poeta e filósofo Rabindranath Tagore, a peça O Mensageiro do Rei (1912) conta, na perspectiva oriental, a história de Amal, um menino que, após perder seus pais, é adotado por seus tios, vivendo sob rígidas ordens médicas, confinado em seu quarto. Doente, observa os dias passarem através de uma janela frontal a uma casa de Correios, o lugar no qual, segundo o garoto, chegará uma mensagem enviada a ele pelo próprio rei, libertando-o para correr mundo afora. Um rei que confunde-se com a figura de um deus.

A peça, que trata de maneira lúdica e lírica a (possível) temática/poética da morte, foi levada à cena por egressos e concluintes do curso de graduação em Teatro da Universidade Federal de Uberlândia. Ficando em cartaz durante os meses de Maio e Junho de 2014, na cidade de Uberlândia-MG, o espetáculo infantojuvenil ganhou forma mediante a encenação de Mário Piragibe, lançando mão da linguagem e dos recursos do Teatro de Formas Animadas (bonecos, objetos, sombras e máscaras) para abordar as questões filosóficas que se fazem presentes na trama mencionada ${ }^{3}$.

\section{Teatro de Formas Animadas}

Mas o que são Formas Animadas? Talvez seja a pergunta que você, leitor, pode estar se fazendo, caso não tenha tanta familiaridade com terminologias ligadas ao universo teatral. Com base nos estudos da professora Ana Maria Amaral (1996, 1997, 2003), designo por Teatro de Formas Animadas, ou Teatro de Animação, o conjunto de manifestações teatrais que se uti-

3.

O Mensageiro do Rei configurouse como uma montagem teatral para a conclusão do curso de Bacharelado em Teatro da Universidade Federal de Uberlândia. Além do professor responsável pela direção da peça, esta montagem contou com o apoio da docente-estagiária Angie Mendonça, responsável pela elaboração e confecção de algumas das Formas Animadas citadas neste texto, e seu elenco era composto pelos seguintes atores: Renata Sanchez, Gabriela Ananda, Jéssica Evans, Karen Marry Quintal, Rafael Michalichem, Rafael Patente, Emilliano

Freitas e Lucas Larcher. 
lizam de bonecos, máscaras, objetos e/ou sombras representando seres antropomórficos, zoomórficos ou ideias abstratas em cena, estes passando do status de matéria inerte para seres com (simulação de) vida, por meio da intervenção do ator, que com eles se relaciona. Ou seja, o teatro cujo inanimado adquire ânima - alma, (princípio de) vida - ou status de animado.

Amaral, em seu livro "Teatro de Formas Animadas" (1996), entre diversas considerações sobre seu tema de interesse, aponta justamente o animismo - ato de fornecer ânima - como uma evidente ligação entre a(s) criança(s) e o Teatro de Animação. Para a autora, o animismo infantil refere-se à tendência de atribuir alma ou vida a fenômenos, elementos da natureza e/ou objetos, explicando suas causas e/ou origens ao momento das primeiras aventuras de descoberta da vida, características da(s) infância(s). Buscando conhecer o mundo, as crianças concedem a seres inanimados - ou a tudo que as rodeiam - sentimentos e ações próprias da figura humana, até então suas maiores referências quanto à possibilidade de existência na Terra. Como elucida a professora:

A criança naturalmente dá vida a tudo que toca. Relaciona-se igualmente com o mundo vegetal, mineral, animal e material. Anima objetos e se comunica com a natureza. Fala com as plantas, com as árvores, com as pedras, colheres e cadeiras, com seu gato, ou com um macaco selvagem criado em sua imaginação, conversa com o vento e com as nuvens. É naturalmente animista. É como se o seu pensamento, ou a sua consciência, estivesse ainda ligada a uma vida anterior, mas à medida em que vai atingindo a idade da razão, vai dela se afastando (AMARAL, 1996, p. 171).

Tendo em vista a passagem do texto acima, fica claro, para mim, que o animismo infantil possibilita a criação de ficcionalidade(s) que se sobrepõe(m) à obviedade e à objetividade de uma lógica racionalista, ao mesclar fantasia e realidade a partir da interação das crianças com seus entornos. Assim, o jogo - ou atividade lúdica - é o ponto de partida para a complexa representação do mundo que a(s) criança(s) faz(em), atribuindo a seres não dotados naturalmente de certas características algo que eles não possuem e/ou são. Ou, em outras palavras, é por meio do lúdico que as crianças podem exercer a atividade animista, utilizando-se, para isso, da capacidade e da expressão simbólica.

Se o símbolo é aquilo que representa, ao mesmo tempo em que é, a si mesmo; ou, então, é o simulacro que é ser em si e outra coisa simultaneamente, as Formas Animadas podem ser consideradas símbolos. Sendo símbolos - bonecos, máscaras, objetos e/ou sombras -, quando animados, apresentam e representam, concomitantemente, uma imagem que se abre para diferentes significados. Significados estes não específicos, e que por si mesmos provocam o ato de reflexão, ou aprendizado. 
Tentando ir além das considerações de Amaral, e com base nos expostos anteriores, digo que embora o animismo possa ser considerado como um evidente vínculo entre as crianças e o Teatro de Formas Animadas, esta operação (intelectual) só é possível de ser realizada por meio do embricamento entre o jogo - ou a ludicidade - e o símbolo - ou a simbolização. Neste sentido, acredito que, dadas as características condicionantes do Teatro de Animação, as Formas Animadas e as crianças possuem profunda ligação justamente pela necessidade de simbolização e ludicidade - fatores característicos do modo de ser/ estar no mundo das crianças - que o animismo requer.

Peter Slade, ao elaborar sua tese de que há uma arte própria da criança, destaca, nas brincadeiras infantis providas de dramaticidade - ou seja, as brincadeiras de faz-de-conta, denominadas pelo autor de jogo dramático infantil -, a capacidade de simbolização como fator determinante para que a criança possa, por meio da atividade lúdica, atribuir a si ou a um objeto a propriedade (simbólica) de ser diferente do que é realmente, ou de representação (apresentar o que está ausente). Retomando as considerações de Slade em O jogo dramático infantil (1978), temos:

[...] existem duas espécies principais de jogo: uma na qual as crianças brincam com objetos e os fazem criar vida (jogo projetado), e a outra na qual as próprias crianças se tornam as pessoas imaginadas, animais ou coisa (jogo pessoal) (SLADE, 1978, p. 25).

Mesmo que as brincadeiras infantis não possam ser compreendidas enquanto "atividade teatral para o autor, já que não se estabelece uma relação palco-plateia, ou a preocupação de construção de um discurso cênico" (DESGRANGES, 2011, p. 93) - como aponta o trecho citado de Pedagogia do teatro: Provocação e dialogismo (2011) -, parece-me ser possível destacar uma grande proximidade entre o jogo projetado - como nomeado por Slade - e o Teatro de Animação. Valendo-se de objetos (bonecos, máscaras, silhuetas para sombras etc.) que, por intermédio do humano, adquirem (a simulação de) vida, tanto o jogo projetado quanto o Teatro de Animação representam - através do simbólico - algo/um ser ausente no decorrer de uma situação lúdica.

Tendo consciência desta proximidade, alguns criadores (dramaturgos/encenadores) ligados ao teatro para as jovens gerações, em nosso país - e no contexto internacional também -, vêm explorando, ao longo de décadas, as relações entre a brincadeira projetada própria da infância e as encenações que se pautam na utilização do Teatro de Animação como um dos constituintes de suas linguagens cênicas. Nomes, tais como 
Maria Clara Machado e Ilo Krugli, além da dramaturga e diretora Sylvia Orthof, são destaques neste assunto, no Brasil ${ }^{4}$.

Embora não acredite que o Teatro de Formas Animadas deve ser ou é restrito ao público infantojuvenil, recordo que este possui um elo histórico com as manifestações espetaculares voltadas para as jovens gerações desde o que denomino de antecedentes destas últimas. Retomando estudos que realizei anteriormente, destaco que os primeiros registros que se têm de apresentações teatrais para crianças e jovens, ao longo dos séculos, referem-se a bonequeiros mambembes na China, no século III a.C., e, mais tarde, entre os séculos XV e XVII, a Commédia dell'arte 5 , dois exemplos de práticas teatrais pautadas na utilização da animação.

Deste modo, sendo as Formas Animadas uma recorrência no Teatro Infantojuvenil, sua presença em O Mensageiro do Rei pode ser interpretada como uma retomada, por parte da montagem, de uma tradição já instaurada no que diz respeito aos elementos expressivos constitutivos $\mathrm{da}(\mathrm{s})$ linguagem(ns) cênica(s) do teatro voltado para as jovens gerações. Em conjunto com o lúdico, as Formas Animadas parecem se destacar na encenação que serve como pano de fundo para esta escrita.

Contudo, este não pode ser apontado como o único motivo pelo qual a animação fez-se presente na poética (ato criativo) do espetáculo. Sendo O Mensageiro do Rei uma montagem que abordava a (possível) temática da morte, é plausível dizer que a exploração do mistério da (simulação de) vida - ânima -, por meio das Formas Animadas, configurava-se como uma escolha, por parte da direção da peça, de estabelecer uma evidente relação entre a encenação e (uma interpretação da) a essência do texto de Tagore. Assim, questões como a materialidade humana ou os diferentes modos de ser/estar no mundo podiam ser vistos em cena - de maneira lírica e simbólica - através de uma profusão de contracenações entre o humano e "as coisas", com o objetivo de contar a história em questão.

..., imaginação e projeção(ões)

Em O Mensageiro do Rei, alguns bonecos - "objeto que, representando a figura humana, ou animal, é dramaticamente animado diante do público" (AMARAL, 2011, p. 71) - eram utilizados para apresentar e representar determinados personagens do espetáculo, aproximando-se do jogo projetado infantil, do qual fala Slade. Contudo, entre outros aspectos, esta situação diferenciava-se da brincadeira de faz-de-conta própria das crianças justamente pela natureza das apresentações teatrais: a presença de público.
4.

Maiores informações sobre a relação entre as criações teatrais voltadas para a infância e a juventude e o Teatro de Animação podem ser observadas, a título de exemplo, por meio da análise das obras Como Fazer Teatrinho de Bonecos (1970), de Maria Clara Machado, Ilo Krugli e a construção de um novo espaço poético para o Teatro Infantil no Brasil (2008), de Miguel Vellinho, e Livro aberto: confissões de uma inventadeira de palco e escrita (1996), de Sylvia Orthof. Nelas os autores expõem alguns apontamentos sobre as relações dos criadores citados neste trabalho com as Formas Animadas e o Teatro Infantojuvenil.

5.

Estas informações são melhor detalhadas no artigo De Versalhes a Kugli: Um Breve Panorama do Teatro Infantojuvenil (2014), publicado na Revista DAPesquisa, e de minha autoria. 
Construídos de materiais singelos ou associação de objetos, os bonecos, que em determinados momentos apresentavam e representavam as personagens Madhav - o tio de Amal -, Takurda - o velho sábio - e Shudha - a menina florista -, faziam lembrar a simplicidade da estruturação de brinquedos pela(s) criança(s). De uma mistura heterogênea de materiais - como o plástico, o látex e tecidos, por exemplo - surgiam, em cena, seres com características humanas que integravam a atividade lúdica - a encenação proposta -, travando diálogo com o universo infantojuvenil.

As formas, ou os modos de apresentação das personagens mencionados há pouco, partiam, assim, da figuração do sujeito por meio de uma perspectiva que remete ao antropomorfismo. Um balão de látex com água e um penico, por exemplo, quando agregados, materializavam o comerciante Madhav. Ou, ainda, um pedaço de tecido, juntamente com uma bola de isopor revestida por uma meia velha, determinava a visualidade de Takurda e/ou de Shudha. Bonecos que contavam, ainda, com a presença de uma bengala e de uma cesta de flores, respectivamente, em suas composições (FIGURA 1).
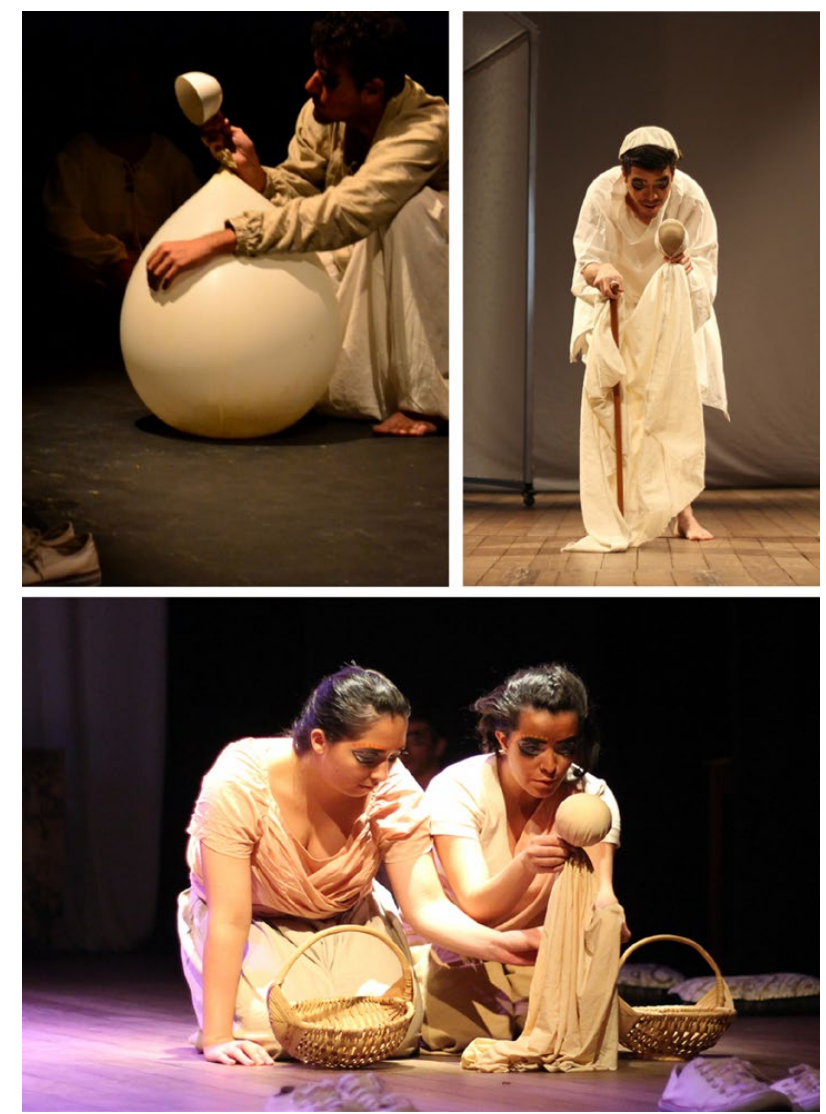

Figura 1

Cena de $\mathrm{O}$

Mensageiro do Rei. Uberlândia - MG, 2014. Fotógrafas: Clara Bevilaqua e Andressa da Mata.

Além disso, é possível dizer que o corpo de alguns dos bonecos dos quais estou falando completava-se em associação 
com os membros de cada ator que os manipulava, e que, neste trabalho, chamarei de ator-manipulador. Como aponta o professor e bonequeiro Paulo Balardim em seu livro Relações de vida e morte no Teatro de Animação (2004, p. 56): "O ator-manipulador é um ator que focaliza sua carga interpretativa em um corpo alheio ao seu, em um objeto ou, ainda, em uma parte específica de seu corpo, ao qual simula autonomia, vontade própria".

Este último era o caso dos atores-manipuladores de Madhav e Takurda, que "emprestavam" seus membros para as constituições físicas dos bonecos a que davam vida. Deste modo, o boneco que apresentava e representava o tio de Amal - nas duas primeiras cenas do espetáculo - tinha seu braço, na primeira cena, a partir do empréstimo de um dos braços de seu manipulador - Rafael Michalichem -; e, na segunda cena, ganhava os membros inferiores, além do braço, através da associação de seu corpo com o da atriz que naquele momento o manipulava - Jéssica Evans.

Já no boneco que apresentava e representava a personagem Takurda, meu braço - uma vez que eu era o ator-manipulador deste boneco -, além de contribuir para sua estruturação física, era suporte para a bengala da personagem. Nestas formas corporais sugeridas, ou incompletas, a possibilidade de metamorfosear era o pressuposto apresentado ao público que, tornando-se cúmplice dos códigos teatrais propostos, permitia que a ficção se tornasse real, assim como o inanimado se tornasse vivo, em um jogo - como já frisado - que remetia às relações/atividades lúdicas entre crianças e seus brinquedos.

Surgidos no que denominamos como Ensaio Afetivo6, os bonecos de Madhav e Takurda ganhavam vida nas mãos de atores que a todo o momento faziam-se presentes e visíveis aos olhos do espectador, constituindo, também, parte do corpo destas personagens. Situação que origina os chamados bonecos geminados - nas palavras de Balardim -, que se incorporam "ao corpo do ator-manipulador simbioticamente, normalmente contracenando com ele" (BALARDIM, 2004, p. 73).

Ao tratar dos brinquedos-sucata - ou seja, objetos não estruturados previamente para a(s) brincadeira(s) infantil(s) -, a professora Marina Marcondes Machado, em O brinquedosucata e a criança (1999), colabora para que pensemos sobre os múltiplos significados que estes objetos - os brinquedos-sucata - podem ser detentores, tal como acredito ter ocorrido com os bonecos dos quais venho falando. Entendendo que os bonecos que apresentavam e representavam Madhav, Takurda e Shudha eram símbolos que convidavam a diferentes significações, e que traduziam, em determinada escala, o universo ficcional proposto na linguagem cênica do espetáculo, é possível dizer que eles propunham uma participação ativa do
6.

Trata-se de um exercício não celebrizado realizado pelo elenco de O Mensageiro do Rei, logo nos primeiros ensaios da peça. Ele consistia na escolha, por parte de cada ator do espetáculo, de um personagem do texto dramatúrgico, assim como de um objeto, um fragmento textual (da peça ou não) e de um gesto que remetessem a personagem escolhida. Todo este material era, então, reunido e, com base em improvisações individuais, davam origem a composições cênicas que foram utilizadas para a criação de futuras cenas do espetáculo, sofrendo alterações de acordo com as necessidades e as proposições da encenação. 
público na construção imaginativa da completude física das Formas Animadas.

Sobre os brinquedos-sucata, ainda, Machado faz alguns apontamentos a partir de sua experiência docente que colaboram e se aproximam do que considero ser um dos principais aspectos com relação à presença dos bonecos supracitados em O Mensageiro do Rei: o despertar para a inventividade/imaginação dos espectadores como co-criadores do espetáculo. Segundo Machado, a respeito de sua práxis:

Procuro estar criando não apenas formas fechadas, belas, harmônicas (como adulto em processo de criação que sou), mas também quero propor à criança a participação ativa, o fazer: que ela sinta vontade de lidar com os materiais e invente, dando a eles a sua forma (que não é a minha, nem a de sua mãe ou a do colega ao lado). (MACHADO, 1999, p. 17)

Mesmo que no espetáculo o público não interviesse na manipulação dos bonecos citados, ao propor uma aproximação destas Formas Animadas com brinquedos ouso dizer que, assim como a criança pode atribuir diferentes significados a brinquedos durante o jogo dramático infantil, o mesmo pode acontecer no Teatro de Animação. Estando os bonecos próximos aos brinquedos, aqueles se tornam uma imagem a ser decodificada. Uma imagem que, embora apresentem e representem as personagens já mencionadas, pode adquirir outros significados na(s) imaginação(ões) da plateia.

Neste sentido, ao propiciar a exploração da imaginação do público, e em especial das crianças, as Formas Animadas em O Mensageiro do Rei - colaboravam para uma aproximação entre os artistas-criadores e a plateia, sendo os primeiros uma espécie de desencadeadores e/ou fomentadores dos processos criativos - imaginativos e sensíveis - de quem assistiu ao espetáculo. E, ainda - de um modo mais geral -, o Teatro de Animação pôde colaborar para a consolidação da proposta de um teatro com crianças e jovens ao permitir que reconhecêssemos que, independente das funções assumidas durante um espetáculo - intérprete e/ou espectador - ambas são responsáveis pela co-criação da obra artística, que, na montagem foco desta reflexão, construía-se como uma espécie de jogo de quebra-cabeça no qual a integração de várias peças resultava na apresentação e na representação das personagens, como continuo a narrar abaixo.

Madhav e Takurda, enquanto bonecos, possuíam corpos e vozes deslocados. Ou seja, suas porções materiais não eram as responsáveis pela emissão de suas vozes. No caso de Madhav, os atores que o manipulavam não eram os mesmos que emprestavam suas vozes ao boneco. Havia um terceiro ator 
- Rafael Patente ou Emilliano Freitas - que, na periferia da área de representação, tornava-se o emissor vocal da Forma Animada e, posteriormente, interpretava a personagem. No caso de Takurda, diferentemente, ao manipular o boneco, emprestava minha voz ao mesmo, uma vez que também interpretava a personagem em diferentes momentos da peça, num jogo de deslocamento da figuração do sujeito-personagem, entre ator e boneco.

Ainda com relação a este aspecto, a boneca que apresentava e representava Shudha ganhava movimento através da manipulação de duas atrizes - Gabriela Ananda e Karen Marry Quintal -, e tinha sua voz também compartilhada por ambas. Deste modo, a única personagem feminina da peça possuía sua configuração corpórea atrelada a uma forma simples de boneca, que podia, ainda, ser interpretada, em determinado momento do espetáculo, como o brinquedo da pequena florista. Isto se pensarmos que a personagem estava desdobrada nas duas atrizes que contracenam com a Forma Animada e que esta era o seu brinquedo... Situação que remete, mais uma vez, às brincadeiras infantis, na encenação observada.

Duplo dos atores - ou formas simbólicas que exerciam a mesma função que seus manipuladores: apresentar e representar as personagens -, os bonecos de Madhav, Takurda e Shudha podem ser caracterizados como desdobramentos do(s) sujeito(s)-personagem(ns), já que, no espetáculo em questão, ora as personagens eram apresentadas e representadas pela interpretação dos atores, ora pelas Formas Animadas, que sofriam intermediação direta dos primeiros, dependendo deles para ganharem vida em cena.

Dominique Houdart, em seu artigo Manifesto por um teatro de marionete e de figura (2007), publicado na revista Móin-Móin, ao se referir à elaborada técnica japonesa do Bunraku, na qual os atores-manipuladores também se fazem visíveis em cena, oferece-nos uma reflexão sobre a relação entre os bonecos e os atores que os manipulam, tal como acontecia em O Mensageiro do Rei. Para o autor:

Visível por detrás da marionete, o manipulador tem uma relação complexa com ela: sombra da personagem, ou seu duplo, ou ainda sua alma, seu deus, anjo ou demônio; relação que prolonga o jogo, que dá um sentido para ele, remete-nos à fabula, extirpa-nos da possível anedota que falseia a teatralidade, remete-nos ao mito ou ao símbolo, sem os quais o teatro já não tem sentido. (HOUDART, 2007, p. 22)

Inspirado pelas palavras de Houdart, acredito que em O Mensageiro do Rei os atores, ao manipularem os bonecos de Madhav, Takurda e Shudha, integravam o jogo proposto pela 
encenação do espetáculo, no qual a teatralidade ${ }^{7}$ constituía um dos elementos essenciais. No entanto, diferentemente do Bunraku - no qual os atores não se desdobram também como personagens -, na peça da qual venho falando víamos um complexo jogo no qual a figuração do sujeito-personagem deslocava-se entre ator(es) e bonecos. O que podia ocorrer dentro de uma mesma cena, ou não, uma vez que as qualidades de apresentação desses personagens, tais como ritmo do andar - no caso de Takurda, amparado por uma bengala -, de caracterização - o som de guizos e a presença da cesta de flores na entrada de Shudha -, e parâmetros vocais - a voz grave de Madhav, por exemplo - eram compartilhados por ambos.

Sobre a questão do ator-manipulador aparente - ou visível - que apresenta e representa a personagem em conjunto com o boneco que manipula, Paulo Balardim - no livro já citado também tece alguns comentários. Para o autor, "o mecanismo de projeção aplicado ao objeto manipulado provoca a possibilidade de o ator ser e não ser." (BALARDIM, 2004, p. 61), além de revelar a própria essência do Teatro de Animação: a representação simbólica por meio da intervenção do ator, que condiciona a fragilidade da (simulação de) vida animada. Mas, para mim, além dos expostos citados, remete, de maneira mais ampla, ao caráter conciliatório entre realidade e fantasia próprio das atividades lúdicas - sejam elas brincadeiras infantis, teatro ou qualquer outra.

Neste sentido, penso que se o ato de se projetar no Teatro de Animação desvenda a própria natureza da representação simbólica, no jogo dramático infantil (projetado) expõe desejos, fantasias, frustrações, afetividades, percepções, expressões, críticas etc. à cultura na qual uma criança está inserida. Mas isto não é tudo! Se o jogo dramático infantil (projetado) permite que os devaneios poéticos, próprios do universo infantil, materializem-se em tempo-espaço, o Teatro Infantojuvenil, ao se aproximar daquele - por meio da animação -, denota, através da expressão estética e simbólica, como os adultos vêm/imaginam as crianças - e/ou a(s) infância(s) - para as quais suas criações dirigem-se.

Trata-se, portanto, em certa instância, do modo como nós, artistas-criadores, abordamos a(s) infância(s) e a(s) criança(s) que a integra(m). Uma abordagem que envolve questões relacionadas à(s) sociedade(s) e sua(s) cultura(s), em diálogo com o universo teatral. Considerando que no Teatro Infantojuvenil há sempre a lógica dos adultos (que escrevem, encenam, concebem e representam) em sua constituição, este remete e acaba por evidenciar em cena aspectos tradicionalmente e/ou culturalmente atribuídos à(s) infância(s) - e à(s) juventude(s) -,
7 .

De acordo com Patrice Pavis, em seu Dicionário de Teatro (2008), "a teatralidade seria aquilo que, na representação ou no texto dramático, é especificamente teatral (ou cênico) no sentido que o entende" (p. 372). Ou, como este mesmo autor incorpora no verbete de seu dicionário: "é o teatro menos o texto, é uma espessura de signos e de sensações que se edifica em cena a partir do argumento escrito, é aquela espécie de percepção ecumênica dos artifícios sensuais, gestos, tons, distâncias, substâncias, luzes, que submerge o texto sob a plenitude de sua linguagem exterior". (BARTHES apud PAVIS, 2008, p. 372). 
sendo um lugar de emergência de significações sobre estas categorias sociais.

Infância(s) em cena

Para que a questão exposta acima fique mais clara, recorro a um exemplo que também se refere à utilização de bonecos em O Mensageiro do Rei. Trata-se da cena em que alguns meninos divertem-se com os brinquedos de Amal, diante da janela do quarto do garoto, no segundo ato do texto, na qual Amal estabelece amizade com os transeuntes da rua para qual a janela de seu quarto é direcionada. No episódio em questão, tínhamos a presença de bonecos que, em conjunto com os atores-manipuladores, apresentavam e representavam as personagens meninos, sendo as estruturações corpóreas destas confeccionadas em espuma, e revestidas com uma miniatura do figurino utilizado no espetáculo.

A relação destes bonecos com os seus manipuladores dava-se pela incorporação da cabeça dos últimos ao corpo de espuma há pouco citado, que ganhava, assim, a dimensão do humano. Metamorfoseados em meninos, através da associação com as Formas (a serem) Animadas, os quatro atores - Rafael Michalichem, Rafael Patente ou Emilliano Freitas, Lucas Larcher e Karen Marry Quintal - participantes da única cena em que estas personagens apareciam eram, concomitantemente, personagens e atores-manipuladores. Ao mesmo tempo em que emprestavam suas faces, seus sentimentos e suas vozes aos bonecos, davam vida a eles através da manipulação de suas mãos, pernas e quadris, à vista do público (FIGURA 2).



Figura 2

Cena de

O Mensageiro do Rei. Uberlândia - MG, 2014. Fotógrafa: Andressa da Mata.

Sobre os dois baús do cenário, que nesta cena serviam de balcões ou suporte para as Formas Animadas, os bonecos 
geminados - retomando a nomenclatura proposta por Balardim - dividiam-se em duas duplas e, em conjunto com seus atores-manipuladores, transformavam a proposição do texto de Tagore em uma sucessão de situações cômicas providas das falas, dos caracteres das personagens e/ou das situações dramáticas . E, ainda, em uma rica fonte de análise que me permite, hoje, relativizar os limites da classificação de jogo(s) - projetado e/ou pessoal - apresentada por Slade, quando aproximado da atividade teatral, uma vez que, no caso dos bonecos geminados, ambos os jogos ocorrem simultaneamente.

Observando com um olhar mais apurado este momento do espetáculo, vejo, agora, que as construções de tais personagens lançaram mão de uma tipificação - exaltação de uma característica central, condicionando todo o comportamento do ser -, e, consequentemente, de uma abordagem simplista das nuances que estas personagens poderiam exibir. Deste modo, metaforicamente, tais construções podem se relacionar com algumas conotações de algo velho ou ultrapassado atribuídas aos baús que serviam de bancada para a manipulação dos bonecos em foco. Ou, em outras palavras, a construção das personagens meninos (crianças) por seus atores-manipuladores referia-se à veiculação de uma determinada "representação de infância" que, embora estivesse ligada à uma sátira, reproduz modelos indenitários infantis atrelados a estereótipos - como a ingenuidade.

Embora o texto de Tagore não contivesse indícios - falas ou didascálias - que poderiam levar a este tipo de elaboração, nós, atores e direção, ao criarmos a cena em questão, recorremos a recursos expressivos - tais como voz caricata (tatibitate), trejeitos ditos infantis e uso de expressões no diminutivo para dar vida e caracterizar as personagens - que apontam, nesta pesquisa, para uma problemática. Uma problemática que retoma as relações entre adultos e crianças, não apenas no teatro.

Ainda no livro citado neste terceiro capítulo, Machado profere alguns apontamentos sobre o(s) modo(s) como os adultos convivem com as crianças, destacando-se, majoritariamente, o papel autoritário - vinculado a uma postura doutrinária, em geral - e/ou protetor - ligado a um excessivo resguardo com relação à(s) criança(s) e a seu(s) entorno(s). Tais modos permitem-me a proposição da hipótese de que no Teatro Infantojuvenil os papeis supracitados são constantemente assumidos pelos atores em cena - ou fora dela -, revelando idealizações de posicionamento perante a(s) infância(s) como também à(s) juventude(s) - para as quais falamos e/ou apresentamos e representamos. Conforme diz autora: 
Os sons, os gestos, o tom de voz, as palavras escolhidas pelo adulto para falar com a criança, nada disso é neutro: cada atitude desse adulto em relação às crianças - e em relação às brincadeiras - traz um significado. (MACHADO, 1999, p. 28)

Seguindo esta linha de raciocínio, digo que, quando representamos crianças e/ou com ela falamos, fazemos um movimento duplo. Ao mesmo tempo em que representamos da maneira como imaginamos que elas pensam, simbolizam e se relacionam com o mundo, revelamos como nos portamos perante elas, como as concebemos e como nos relacionamos com elas. Em O Mensageiro do Rei, ao levarmos à cena - inconscientemente e indesejadamente - representações tipificadas e/ ou estereotipadas de crianças, acabamos por propiciar uma reflexão neste artigo sobre a dificuldade de romper com alguns padrões ou modelos engendrados no meio artístico - e em toda a sociedade - quanto ao(s) modo(s) como nos relacionamos com a(s) infância(s) e tudo aquilo dirigido e/ ou produzido por/para/com ela(s).

Além disso, nesta mesma cena, ao apresentarmos alguns momentos de violência entre crianças, remetemos, curiosamente, à complexidade da categoria social que elas integram. Afinal, a(s) infância(s) não é(são) uma época apenas de pureza e alegria, mas, sim, mais uma etapa da vida do ser humano. E, nesta, comportamentos agressivos e em desacordo com as convenções sociais também existem. Aspectos estes retomados pelos tradicionais espetáculos de bonecos de luva, tão exploradas no contexto teatral infantojuvenil europeu até a década de sessenta do século passado. Como, por exemplo, nas apresentações de Punch and Judy ${ }^{8}$, que se caracterizam pelo extremo nonsense e pela constante violência em seus enredos, além das improvisações realizadas entre os manipuladores, tal qual o espetáculo foco deste texto.

Em contraposição à atitude de violência trazida pela cena em que figuram as personagens meninos, o modo escolhido para apresentar e representar Amal no primeiro e no segundo ato do espetáculo revela uma caracterização ingênua e angelical da personagem - que se acentuava devido à condição enferma da criança. De maneira também estereotipada, em alguns momentos da peça ficava evidente a postura protetora perante à(s) criança(s) por parte da equipe criativa da montagem.

Levada à cena sob a forma de uma sombra ${ }^{9}$ durante os dois primeiros atos da peça, Amal tinha sua composição física exposta através da projeção, em uma tela presa a uma estrutura cenográfica, de uma silhueta construída em madeira. Tendo como suporte um pequeno cavalete, esta silhueta era constituída pela parte de cima do tronco do menino, sua cabeça e seus braços, numa perspectiva de perfil (FIGURA 3).
8.

Trata-se de uma manifestação teatral específica, cujas origens remontam à personagem Polichinelo da Commédia dell'arte. Esta personagem, ao ser incorporada ao teatro de bonecos, foi caracterizada por modos grosseiros e temperamento intolerante, obtendo sucesso e se difundindo pelos teatros de bonecos de diversos países. Com o tempo, tornou-se conhecida como Guignol, na França, Pulcinella, na Itália, João Redondo ou João Minhoca, no Brasil, e Punch, na Inglaterra. O último, em especial, gradativamente atraiu a atenção das crianças, tornando-se atração típica do teatro a elas dirigido. Agindo ao lado de sua esposa (Judy), Punch consolidou-se como um dos mais populares personagens ingleses, dando seu nome e de sua esposa a espetáculos de bonecos na Europa, Ásia, África e América.

9.

Fenômeno óptico que, no teatro, é explorado pela manipulação de uma silhueta de varas, na presença de um objeto, ou até mesmo na expressão de um corpo humano entre uma fonte luminosa e uma superfície ou tela, o que faz com que o espectador, sentado diante destas, veja a sombra projetada. Historicamente, o Teatro de Sombras teria se originado na Índia ou na China, conforme relata uma antiga lenda que remonta ao século II a.C. No entanto, é somente no final do século XVII que se encontram os primeiros registros de apresentações de Teatro de Sombras na Europa. Dentre estas, destaca-se o primeiro espetáculo teatral formalmente dirigido a crianças e jovens: uma peça de Dominique Séraphin, com apresentação no Palais Royal em Versalhes, na França, o Spectacle des Enfants (1781) 


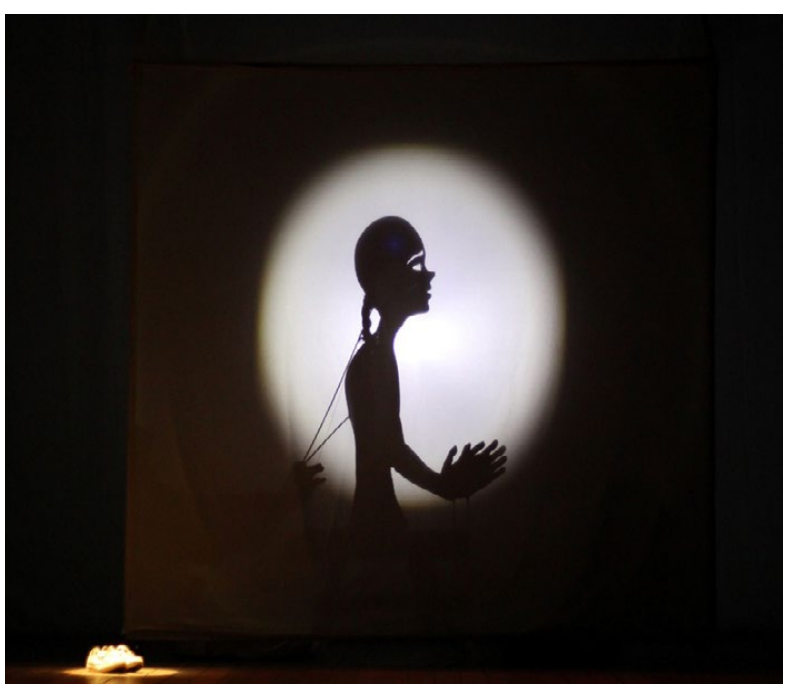

Figura 3

Cena de $O$

Mensageiro do Rei. Uberlândia - MG, 2014. Fotógrafas: Clara Bevilaqua e Andressa da Mata.

Como alguém que está sentado na janela, a imagem do menino era projetada numa tela - feita de tule: tecido que, no ocidente, tradicionalmente serve de invólucro pra o berço dos recém-nascidos e para as urnas funerárias, conferindo ao corpo humano proteção -, por meio de uma lanterna com alta potência luminosa. Assim, a tela configurava-se como uma espécie de janela que intermediava as relações entre menino e o mundo. E a luz advinda da lanterna permitia que não só a figuração do sujeito Amal fosse vista, mas também a explicitação dos traços delicados da imagem.

Manipulada, na grande maioria das vezes, por dois atores, num jogo de revezamento existente entre grande parte do elenco, a silhueta de Amal possuía pequenos vazamentos que permitiam a passagem de luz, dando maiores capacidades expressivas à Forma Animada. Contando com três varas de metal para a manipulação - uma em cada um dos dois pulsos e outra na cabeça -, além de um gatilho que permitia o movimento de abrir e fechar de olhos do menino, a silhueta propiciava, ainda, que os atores-manipuladores pudessem realizar uma seleção de movimentos, em sintonia com o caráter ingênuo e angelical da personagem, que, assim, ganhava vida... E, por falar em vida, tal como ocorria com Madhav, Amal tinha sua voz advinda não de seus manipuladores, mas, sim, da presença de uma atriz à margem da cena que vocalizava a figura, por vezes, de maneira doce e idealizada. O que, no seu entendimento, revela uma representação a partir de uma visão estereotipada, reducionista ou simplificada da(s) infância(s).

Dando pistas para uma reflexão mais burilada quanto à relação acerca da representação $\mathrm{da}(\mathrm{s})$ infância(s) em $\mathrm{O}$ Mensageiro do Rei, através de apontamentos sobre brinquedos destinados às crianças, o professor francês Gilles Brougère propõe, em seu livro Brinquedo e Cultura (2010), a metá- 
fora da boneca industrializada como espelho da sociedade. Estabelecendo, mais uma vez, um paralelo entre as Formas Animadas utilizadas no espetáculo em questão e os objetos produzidos para a atividade lúdica infantil, recorro às ideias do autor, para que, com base em minha experiência no espetáculo em destaque, possa apresentar mais alguns apontamentos pertinentes sobre $\mathrm{o}$ assunto.

Para Brougère, "o mundo da boneca reflete mais uma imagem social da realidade do que a própria realidade social" (BROUGERE, 2010, p. 36). Tratando-se de um reflexo do reflexo, a boneca seria, então, uma representação arbitrária que media o "mundo dos adultos" e o "mundo das crianças" a partir de uma idealização - deformada - construída pelos pertencentes ao primeiro. Esta representação seria, definitivamente, uma imagem manipulável do que se imagina ser a(s) criança(s) - e/ou a(s) infância(s) -, que, contida em um espelho mágico - como fala o autor -, estrutura-se a partir das suposições de como a criança compreende e apreende o mundo para si. Para o professor:

[...] a boneca reflete para nós, depois de muitas mediações e transformações, nossas próprias representações, diretas ou indiretas, da infância, esse "outro mundo", retomando a expressão da socióloga francesa M. J. Chombart de Lauwe. Portanto, não é surpreendente que desperte nos adultos, colecionadores ou não, nostalgia e apego. Ela expressa, efetivamente, uma imagem atraente, sedutora, da infância, como ideal que ultrapassa a criança real. A boneca, imagem feita para seduzir, exprime, melhor do que a própria criança, a infância. (BROUGERE, 2010, p. 38)

A partir desta citação, destaco que, no meu entender, assim como a boneca industrializada evidencia um descompasso entre as maneiras como o "mundo das crianças" é idealizado por adultos e se apresenta na realidade, em O Mensageiro do Rei algo semelhante ocorreu. Parece-me que os modos de apresentação e representação escolhidos para Amal e os meninos, enquanto Formas Animadas - com (simulação de) vida através da manipulação de atores - não salientavam as crianças como pertencentes à(s) infância(s) com suas dicotomias, enquanto categoria social instável como a conhecemos hoje. Ao contrário, reproduzia clichês, tipificações ou estereótipos de crianças a partir de uma postura não autoritária dos adultos (artistas-criadores), mas, em certa escala, protetora, que não parecia estar em diálogo com os modos de ser, compreender e pensar a(s) infância(s) atualmente.

Machado, em consonância com os apontamentos apresentados neste artigo, ajuda-nos a lembrar, mais uma vez, que, na atual conjectura estabelecida em nossa sociedade, as fronteiras entre os mundos "dos adultos" e "das jovens gerações" estão 
borrados. Em seu artigo A criança é performer (2010), publicado na revista Educação \& Realidade, a autora diz:

A visão da infância que vou desenhar parte da certeza de que a criança compartilha o mesmo mundo do adulto: vê, percebe, vive o mundo em sua própria perspectiva, sim, mas nunca ensimesmada ou reclusa em um "mundo da criança"; vivemos o mesmo mundo, convivemos no mesmo mundo." (MACHADO, 2010, p. 117)

Desta maneira, sendo a(s) infância(s) território(s) de antíteses e complexidades, tudo que a ela(s) se dirige e/ou que por/ com ela(s) é produzido, carrega, em maior ou menor escala, a marca do universo daquilo que se julga ser "adulto". Tal fato pode ser constatado, por exemplo, na imagem (expressiva) da boneca industrializada - como cita Brougère -, assim como na manipulação/construção das personagens meninos e Amal, em o Mensageiro do Rei. Ambos exemplos detentores de constituições que mesclam características ditas "infantis" e "adultas", mas, antes de tudo, inerentes a qualquer ser humano.

Exploradas em algumas minúcias, neste texto, as Formas Animadas presentes em $O$ Mensageiro do Rei - que não remetem ao universo indiano do texto e aludido pela encenação - fazem-me lembrar a complexa trama na qual a cena de um espetáculo se constitui, em que diferentes sistemas de signos interagem, possibilitando ao espectador associações e interpretações diversas sobre o fenômeno teatral.

Maria Lúcia Pupo, ao escrever seu artigo O lúdico e a construção do sentido (2001), publicado na revista Sala Preta, frisa justamente a complexa trama de significações que compõem uma encenação. Referindo-se a objetos, a autora destaca que "a dimensão lúdica da relação entre significante e significado vem sendo ressaltada em nosso teatro mais recente" (PUPO, 2001, p. 184), o que pode ser, perfeitamente, expandido para o caso das Formas Animadas, em geral. E é justamente isso o que acorria em $O$ Mensageiro do Rei.

No espetáculo em questão, as Formas Animadas utilizadas para apresentarem e representarem as personagens já citadas não apenas remetiam à materialidade de Amal, Madhav, Takurda, Sudha e meninos, mas também traziam consigo diferentes cargas simbólicas atribuídas à(os) bonecos(as) em nossa cultura. E, ainda, acabavam por demonstrar que uma personagem pode transformar sua constituição material/ física, dando continuidade à sua existência, apesar da diferença de aspecto. Através do embricamento entre o lúdico, o animismo e a imaginação, evidenciavam que entre o real e o mágico, a vida e a morte, há uma interpenetração em que as demarcações de fronteiras desaparecem. 


\section{REFERÊNCIAS}

AMARAL, Ana Maria. Teatro de Formas Animadas: Máscaras, Bonecos, Objetos. 3.ed. São Paulo: Edusp, 1996.

Teatro de animação. São Paulo: Ateliê

Editorial, 1997.

O ator e seus duplos. 2.ed. São Paulo:

SENAC, 2003.

BALARDIM, Paulo. Relações de vida e morte no teatro de animação. Porto Alegre: Edição do Autor, 2004.

BROUGÈRE, Gilles. Brinquedo e cultura. 8 ed. São Paulo: Cortez, 2010.

DESGRAngeS, Flávio. A Pedagogia do Teatro: Provocação e Dialogismo. 3.ed. São Paulo: Hucitec, 2011.

HOUDART, Dominique. Manifesto por um teatro de marionete e de figura. Móin-Móin: Revista de estudos sobre Teatro de Formas Animadas, Jaraguá do Sul: SCAR/UDESC, 2007, ano 3, n. 4., p. 13-32.

LARCHER, Lucas. De Versalhes a Kugli: Um Breve Panorama do Teatro Infantojuvenil. DAPesquisa, 2014, v. 11, p. 32-45.

Inventariando $O$ Mensageiro do Rei

- reflexões e discussões acerca do Teatro Infantojuvenil. Dissertação (Mestrado em Artes) - Instituto de Artes, Universidade Federal de Uberlândia (UFU), Uberlândia, 2016.

MACHADO, Maria Clara. Como Fazer Teatrinho de Bonecos. Rio de Janeiro: Agir, 1970.

MACHADO, Marina Marcondes. O brinquedo-sucata e a criança. 3.ed. São Paulo: Edições Loyla, 1999.

A criança é performer. Educação \&

Realidade, Porto Alegre, 2010, v.35, n.2, p. 115-137.

ORTHOF, Sylvia. Livro aberto: confissões de uma inventadeira de palco e escrita. São Paulo: Atual, 1996.

PAVIS, Patrice. Dicionário de Teatro. 3.ed. São Paulo: Perspectiva, 2008.

PAZ, Octavio; CAMPOS, Haroldo. Transblanco (em torno a Blanco de Octavio Paz). São Paulo: Siciliano, 1994.

PUPO, Maria Lúcia de Souza Barros. O lúdico e a construção do sentido. Sala Preta, 2001, São Paulo, p. 181-187, jun. 2001.

SLADE, Peter. Ojogo dramático infantil. São Paulo: Summus, 1978. TAGORE, Rabindranath. O Mensageiro do Rei. [S.I.]: [s.n.], 1912. (Tradução de Mário Piragibe).

VIEIRA, Miguel Vellinho. Ilo Krugli e a construção de um novo espaço poético para o Teatro Infantil no Brasil. 2008. Dissertação (Mestrado em Teatro) - Centro de Letras e Artes, Universidade Federal do Estado do Rio de Janeiro (UNIRIO), Rio de Janeiro, 2008. 